\title{
Investigation of single-strand conformational polymorphism of the TP53 gene in women with a family history of breast cancer
}

R.R. Burbano ${ }^{1}$,

A.C. Medeiros ${ }^{5}$,

A.A. Mello

J.A. Lemos Lem, $^{2,4}$

M.O. Bahia ${ }^{3}$ and

C. Casartelli6
Departamentos de ${ }^{1}$ Biologia, ${ }^{2}$ Genética, and ${ }^{3}$ Patologia, Centro de Ciências Biológicas, Universidade Federal do Pará, and ${ }^{4} \mathrm{H}$ emocentro do Pará, Belém, PA, Brasil

${ }^{5}$ Departamento de Biologia Molecular, U niversidade Federal da Paraíba, João Pessoa, PB, Brasil

${ }^{6}$ Departamento de Genética, Faculdade de Medicina de Ribeirão Preto, Universidade de São Paulo, Ribeirão Preto, SP, Brasil

\section{Correspondence}

R.R. Burbano

Departamento de Biologia

CCB, UFPa

Av. Augusto Correia, 01

66075-900 Belém, PA

Brasil

Fax: +55-91-211-1601

E-mail: rommel@ufpa.br

Research supported by UFPa, HEM O Pa, UFPb, USP, FAPESP,

CAPES and CNPq.

Received January 19, 2000

Accepted August 7, 2000

\section{Abstract}

Breast cancer in families with germ line mutations in the TP53 gene has been described in the medical literature. Mutation screening for susceptibility genes should allow effective prophylactic and preventive measures. Using single-strand conformational polymorphism, we screened for mutations in exons 5, 6, 7 and 8 of gene TP53 in the peripheral blood of 8 young non-affected members ( 17 to 36 years old) of families with a history of breast cancer. Studies of this type on young patients (mean age, 25 years) are very rare in the literature. The identification of these mutations would contribute to genetic counseling of members of families with predisposition to breast cancer. The results obtained did not show any polymorphism indicating mutation. In our sample, the familial tumorigenesis is probably related to other gene etiologies.

Numerous risk factors for the development of breast cancer have been identified. Family history, suggesting an inherited component in the development of some breast cancers, is one of the strongest known risk factors. It is estimated that 15 to $20 \%$ of women with breast cancer have a family history of the disease (1). Alterations of tumor suppressor gene TP53 (encoding p53) are found in half of all tumors (2). The strongest link between TP53 mutations and breast cancer is based on the increased incidence of early-onset breast cancer seen in LiFraumeni syndrome, the family cancer syn-

\section{Key words}

- TP53

- Family history of breast

cancer

- Mutation screening

- Early breast cancer drome caused by germ line alterations in the TP53 gene (3).

In sporadic breast tumors as well as in the germ line of family members with a history of breast cancer, most of the mutations in the TP53 gene are found in exons 5 to 8 (4-6). By using single-strand conformational polymorphism (SSCP), we performed a mutation screening in exons 5, 6,7 and 8 of the tumor suppressor gene TP53 in the peripheral blood of 8 young women with a family history of breast cancer. Previous identification of the carriers of mutations in the TP53 gene would contribute to genetic counseling and treat- 
ment of young patients with cancer.

In the present study, 8 blood samples from young women belonging to families from Pará, Brazil, with a history of breast cancer were analyzed. The family history and the detailed assessment of the age-specific risk of breast cancer in the women of our sample with relatives affected with the disease were based on data from a population-based, case control cancer and steroid hormone study, which can be used for individual risk assessment (Table 1) (7). A blood sample from young women with no family

Table 1 - Family history of breast cancer for the women of our sample and assessment of the age-specific risk of breast cancer in women whose relatives developed breast cancer (from Ref. 7).

aPopulation risk for breast cancer at age 40-50 is 1 in 100 (1\%). bPopulation lifetime risk (age 20-80 years) is 1 in 12. 'Relatives' include first-degree relatives (mother, father, brother, sister, child). A relative with bilateral breast cancer counts as two. In our sample, all relatives are dead.

\begin{tabular}{lcccc}
\hline $\begin{array}{l}\text { Case } \\
\text { (initials) }\end{array}$ & $\begin{array}{c}\text { Age } \\
\text { (years) }\end{array}$ & $\begin{array}{c}\text { Family history of } \\
\text { breast cancer }\end{array}$ & $\begin{array}{c}\text { Expected risk of } \\
\text { breast cancer } \\
\text { between } 40 \text { and } \\
50 \text { years }\end{array}$ & $\begin{array}{c}\text { Lifetime } \\
\text { risk }\end{array}$ \\
\hline 1 (MSS) & 17 & 2 relatives $>60$ years & $<1$ in 45 & $<1$ in 7.5 \\
2 (RSP) & 36 & 2 relatives $>60$ years & $<1$ in 45 & $<1$ in 7.5 \\
3 (EQL) & 18 & 2 relatives $>60$ years & $<1$ in 45 & $<1$ in 7.5 \\
4 (YPS) & 35 & 2 relatives $>60$ years & $<1$ in 45 & $<1$ in 7.5 \\
5 (MEL) & 22 & 2 relatives $>60$ years & $<1$ in 45 & $<1$ in 7.5 \\
6 (ECC) & 22 & 2 relatives 50-60 years & $>1$ in 25 & 1 in 4 \\
7 (ECF) & 17 & 2 relatives $50-60$ years & $>1$ in 25 & 1 in 4 \\
8 (SRA) & 35 & 2 relatives 50-60 years & $>1$ in 25 & 1 in 4
\end{tabular}

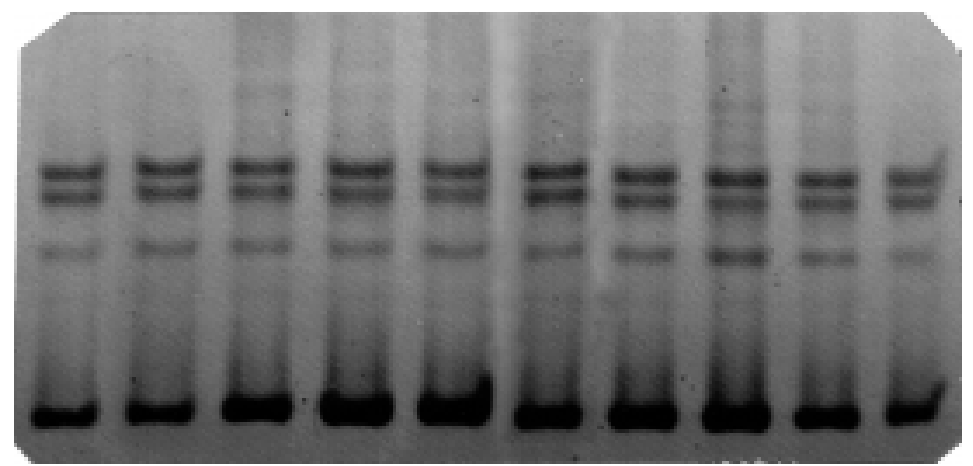

Control Case 1 Case 2 Case 3 Case 4 Control Case 5 Case 6 Case 7Case 8

Figure 1 - Single strand of exon 8 of gene TP53. Polyacrylamide gel with 10\% glycerol. The gel was stained with silver nitrate. Single-strand conformational polymorphism did not show any polymorphism indicating mutation. history of breast cancer was used as the control.

DNA was extracted from $10 \mathrm{ml}$ of whole blood as described by Sambrook et al. (8).

Primers (9) were used to amplify exons 5, 6,7 and 8 of the TP53 gene. Approximately $200 \mathrm{ng}$ of genomic DNA was mixed with 50 pmol of each primer and Taq polymerase buffer (Cenbiot, Porto Alegre, RS, Brazil), at a final concentration of $10 \mathrm{mM}$ Tris- $\mathrm{HCl}, \mathrm{pH}$ 8.4, $50 \mathrm{mM} \mathrm{KCl}$ and $1.5 \mathrm{mM} \mathrm{MgCl}_{2}, 50 \mathrm{mM}$ of each triphosphated deoxynucleotide, and 1.25 units of Taq polymerase. Amplifications were carried out using a Perkin Elmer/ Cetus (Norwalk, CT, USA) thermal cycler under the following conditions: 1 cycle at $95^{\circ} \mathrm{C}$ for $5 \mathrm{~min}, 35$ cycles at $95^{\circ} \mathrm{C}$ for $1 \mathrm{~min}$, $60^{\circ} \mathrm{C}$ for $1 \mathrm{~min}, 72^{\circ} \mathrm{C}$ for $1 \mathrm{~min}$, and 1 cycle at $72^{\circ} \mathrm{C}$ for $7 \mathrm{~min}$.

For SSCP analysis, the DNA was amplified by PCR using the specific p53 gene primers described above. After the reaction, the products were diluted in $100 \mu \mathrm{l}$ of a solution of $0.1 \%$ SDS and $10 \mathrm{mM}$ EDTA. Three microliters of the diluted sample was mixed with $4 \mu \mathrm{l}$ of formamide stain, denatured for $10 \mathrm{~min}$ at $95^{\circ} \mathrm{C}$ and kept refrigerated prior to application to the gel. Electrophoresis was carried out on $40 \mathrm{~cm}$ of $5-10 \%$ polyacrylamide gel containing $10 \%$ glycerol for $16-18 \mathrm{~h}$ at $6 \mathrm{~W}$ and room temperature (10). The single-strand DNA was stained with silver nitrate.

The deactivation of tumor suppressor genes is a common genetic mechanism in breast cancer, and is of considerable significance for the pathogenesis of human cancer (11). Thus, kindreds with germ line mutations of the TP53 gene can now be screened closely from an early age for the development of tumors, as their risk is extremely high (12). We checked whether the conformational alterations in TP53 exons 5, 6, 7 and 8 detected in the PCR-SSCP test were initial events in the genesis of familial breast cancer. No alterations were found in our sample (Figure 1). 
The family history can be an indicator of a hereditary disorder. Family characteristics indicating hereditary cancer are a) two or more first-degree relatives with the same malignity and/or b) two or more first-degree relatives with rare tumors (13). The women in our sample present these characteristics (Table 1).

Literature studies also did not detect constitutional mutations of gene TP53 in members of families with a history of breast cancer or in patients with multiple primary tumors $(4,14,15)$. Germ line mutations in TP53 have been identified as rare causes of hereditary breast cancer (16), although TP53 mutations may be a more important cause of cases of very early-onset breast cancer (12). Mutations in this gene seem to be exclusive characteristics of patients with Li-Fraumeni syndrome, the rare syndrome of family cancer characterized by a high incidence of breast carcinoma and other neoplasias (6).
Therefore, germ line alterations in gene TP53 probably are not a significant cause of familial breast cancer $(17,18)$.

In our sample, familial tumorigenesis may have been related to other genic etiologies or to other segments of the TP53 gene not analyzed in this study. Two other major breast cancer susceptibility genes (BRCA1 and BRCA2) have been identified $(19,20)$ and others are being actively sought. It is very likely that other, lower penetrance genes are responsible for inherited susceptibility to breast cancer in families in which the incidence of breast cancer is higher than that in the general population but the inheritance pattern does not fit the classic model of Mendelian inheritance (1).

The study of breast cancer susceptibility genes has greatly expanded our knowledge of inherited breast cancer, and of development markers for genetic counseling of women with a family history of breast cancer.

\section{References}

1. Couch FJ \& Weber BL (1998). Breast cancer. In: Vogelstein B \& Kinzler KW (Editors), The Genetic Basis of Human Cancer. McGraw-Hill, New York, USA.

2. Poremba $C$, Bankfalvi $A \&$ DockhornDworniczak B (1996). Tumor suppressor gene p53. Theoretical principles and their significance for pathology. Pathologe, 17: 181-188.

3. Malkin D, Li FP, Strong LC, Fraumeni J $r$ J F, Nelson CE, Kim DH, Kassel J , Gryka MA, Bischoff FZ \& Tainsky MA (1990). Germ line p53 mutations in a familial syndrome of breast cancer, sarcomas, and other neoplasms. Science, 250: 12331237.

4. Warren W, Eeles RA, Ponder BAJ , Easton DF, Averill D, Ponder MA, Anderson K, Evans AM, Demars R, Love R, Dundas $S$, Stratton MR, Trowbridge P, Cooper CS \& Peto J (1992). No evidence for germline mutations in exons 5-9 of the p53 gene in 25 breast cancer families. Oncogene, 7: 1043-1046.

5. Chakravarty GM, Redkar A \& Mittra I (1996). A comparative study of detection of p53 mutations in human breast cancer by flow cytometry, single-strand confor- mation polymorphism and genomic sequencing. British J ournal of Cancer, 74: 1181-1187.

6. Frebourg T (1997). Li-Fraumeni syndrome. Cancer, 84: 735-740.

7. Claus EB, Risch N \& Thompson WD (1994). Autosomal dominant inheritance of early-onset breast cancer. Implications for risk prediction. Cancer, 73: 643-651.

8. Sambrook J, Fritsch EF \& Maniatis T (1989). Molecular Cloning: A Laboratory Manual. 2nd edn. Cold Spring Habor Laboratory Press, Cold Spring Habor.

9. Hurlimann J, Chaubert $P \&$ Benhattar J (1994). p53 gene alterations and p53 protein accumulation in infiltrating ductal breast carcinomas: correlation between immunohistochemical and molecular biology techniques. Modern Pathology, 7: 423-427.

10. Orita M, Iwahana $\mathrm{H}$, Kanazawa $\mathrm{H}$, Hayashi K \& Sekiya T (1989). Detection of polymorphisms of human DNA by gel electrophoresis as single-strand conformation polymorphisms. Proceedings of the National Academy of Sciences, USA, 86: 2766-2770.

11. Medeiros AC, Nagai MA, Neto MM \&
Brentani RR (1994). Loss of heterozygosity affecting the APC and MCC genetic loci in patients with primary breast carcinomas. Cancer Epidemiology, Biomarkers and Prevention, 3: 331-333.

12. Wasan HS \& Bodmer WF (1998). Inherited susceptibility to cancer. In: Franks LM \& Teich NM (Editors), Introduction to the Cellular and Molecular Biology of Cancer. 3rd edn. Oxford University Press, Oxford, UK.

13. Malkin D (1994). p53 and the Li-Fraumeni syndrome. Biochimica et Biophysica Acta, 1198: 197-213.

14. Hodgson SV \& Maher ER (1999). Human Cancer Genetics. 2nd edn. Cambridge University Press, Cambridge, UK.

15. Shiseki M, Nishikawa R, Yamamoto, $H$, Ochiai A, Sugimura $H$, Shitara N, Sameshima $Y$, Mizoguchi $H$, Sugimura $T \&$ Yokota J (1993). Germ-line p53 mutation is uncommon in patients with triple primary cancers. Cancer Letters, 73: 51-57.

16. Borrensen AL, Andersen $\mathrm{TI} \&$ Garber J (1992). Screening for germline TP53 mutations in breast cancer patients. Cancer Research, 52: 3234-3236.

17. Prosser , Elder PA, Condie A, MacFadyen 
I, Steel CM \& Evans HJ (1991). Mutations in p53 do not account for heritable breast cancer: a study in five affected families. British J ournal of Cancer, 63: 181-184.

18. Eeles RA (1993). Predictive testing for germline mutations in the $\mathrm{p} 53$ gene: are all the questions answered? European J ournal of Cancer, 10: 1361-1365.

19. Miki Y, Swensew J, Shattuck-Eidens D,
Futreal A, Harshman $K$ \& Tavtigian $S$ (1994). A strong candidate for the breast and ovarian cancer susceptibility gene BRCA1. Science, 266: 66-71.

20. Wooster R, Bignell G, Lancaster J , Swift S, Seal S, Mangion J, Collins N, Gregory S, Gumbs C, Micklem G, Barfoot R, Hamoudi R, Patel S, Rice C, Biggs $P$, Hashim Y, Smith A, Connor F, Arason A,
Gudmundsson J, Ficenec D, Kelsell D, Ford D, Tonin P, Bishop DT, Spurr NK Ponder BAJ , Eeles R, Peto J , Devilee P, Cornelisse C, Lynch H, Narod S, Lenior G, Egilsson V, Barkadottir RB, Easton DF, Bentley DR, Futreal PA, Ashworth A \& Stratton MR (1995). Identification of the breast cancer susceptibility gene BRCA2. Nature, 378: 789-792. 